\title{
Pristine and Poly(Dimethylsiloxane) Modified Multi-Walled Carbon Nanotubes as Supports for Lipase Immobilization
}

\author{
Iryna Sulym ${ }^{1, * \mathbb{C}}$, Jakub Zdarta ${ }^{2, *} \mathbb{C}$, Filip Ciesielczyk ${ }^{2}$, Dariusz Sternik ${ }^{3}$, Anna Derylo-Marczewska ${ }^{3}$ \\ and Teofil Jesionowski ${ }^{2}$ (D) \\ 1 Chuiko Institute of Surface Chemistry of NASU, 17 General Naumov Str., 03164 Kyiv, Ukraine \\ 2 Institute of Chemical Technology and Engineering, Faculty of Chemical Technology, Poznan University of \\ Technology, Berdychowo 4, 60965 Poznan, Poland; Filip.Ciesielczyk@put.poznan.pl (F.C.); \\ teofil.jesionowski@put.poznan.pl (T.J.) \\ 3 Institute of Chemical Sciences, Maria Curie-Sklodowska University in Lublin, M.C. Sklodowska Sq.3, \\ 20031 Lublin, Poland; dsternik@poczta.umcs.lublin.pl (D.S.); annad@hektor.umcs.lublin.pl (A.D.-M.) \\ * Correspondence: irynasulym@ukr.net (I.S.); jakub.zdarta@put.poznan.pl (J.Z.); Tel.: +38-044-422-96-72 (I.S.); \\ $+48-61-665-3747$ (J.Z.)
}

check for

updates

Citation: Sulym, I.; Zdarta, J.; Ciesielczyk, F.; Sternik, D.;

Derylo-Marczewska, A.; Jesionowski,

T. Pristine and Poly(Dimethylsiloxane) Modified Multi-Walled Carbon Nanotubes as Supports for Lipase Immobilization. Materials 2021, 14, 2874. https://doi.org/10.3390/ ma14112874

Academic Editor: Klára Hernádi

Received: 11 May 2021

Accepted: 25 May 2021

Published: 27 May 2021

Publisher's Note: MDPI stays neutral with regard to jurisdictional claims in published maps and institutional affiliations.

\begin{abstract}
The presented study deals with the fabrication of highly stable and active nanobiocatalysts based on Candida antarctica lipase B (CALB) immobilization onto pristine and poly(dimethylsiloxane) modified MWCNTs. The MWCNTs/PDMS nanocomposites, containing $40 \mathrm{wt} \%$ of the polymer with two molecular weights, were successfully synthesized via adsorption modification. The effect of PDMS chains length on the textural/structural properties of produced materials was studied by means of the nitrogen adsorption-desorption technique, Raman spectroscopy, and attenuated total reflectance Fourier transform infrared spectroscopy. P-MWCNTs and MWCNTs/PDMS nanocomposites were tested as supports for lipase immobilization. Successful deposition of the enzyme onto the surface of P-MWCNTs and MWCNTs/PDMS nanocomposite materials was confirmed mainly using ATR-FTIR spectroscopy. The immobilization efficiency, stability, and catalytic activity of the immobilized enzyme were studied, and the reusability of the produced biocatalytic systems was examined. The presented results demonstrate that the produced novel biocatalysts might be considered as promising materials for biocatalytic applications.
\end{abstract}

Keywords: multi-walled carbon nanotubes; poly(dimethylsiloxane); polymer nanocomposites; Candida antarctica lipase B; lipase immobilization; enzymes stability and reusability

\section{Introduction}

Carbon occurs in many forms, and the properties of each form with respect to their special structure make carbon a truly unique building block for nanomaterials [1]. Owing to their interesting electrical, magnetic, mechanical, and thermal properties, carbon nanotubes (CNTs) have become the most promising materials in many scientific and technological fields [2-7]. CNTs are made of one or more graphene sheets rolled-up to form tubes. Single-walled CNTs (SWCNTs) comprise a single graphene layer seamlessly wrapped into a cylindrical tube. Multi-walled carbon nanotubes (MWCNTs) comprise an array of concentric cylinders coaxially arranged around a central hollow core with van der Waals forces between adjacent layer [8,9]. CNTs exhibit extremely high surface area, large aspect ratio, low density, remarkably high mechanical strength, and electrical as well thermal conductivities $[8,10]$. Functionalization of carbon nanotube surfaces can be proceeded viacovalent or non-covalent modification. Non-covalent surface modificationof CNTs, which includes adsorption of surfactants, polymers, or biological macromolecules, is a method that does not affect their intrinsic structure [11]. Among many methods, non-covalent attachment (polymer wrapping and absorption) is of key importance when CNTs functionalize with polymer molecules [11-13]. Polymeric materials includingsilicon rubbers, 
in particular poly(dimethylsiloxane) (PDMS), are used in everyday materials. It is related to their excellent durability and mechanical properties that results from their high crosslinking density and degree of polymerization. PDMS is hydrophobic, chemically inert, and electrically resistant, and exhibits dielectric strength, high elasticity, and easy processing and isenvironmentally-friendly [14-17]. The addition of PDMS to MWCNTs improves the mechanical, electrical, and thermal properties of the resulting nanocomposites [18-20]. Based on our previous studies [21-25] concerning materials prepared in a similar way but containing chemically different highly dispersed nano-oxides as well as PDMS modified MWCNTs, it was proved thatpolymer-filler interactions depend on nanocomposite compositions and inorganic particle types (oxides). On the other hand, those interactions are responsible for surface properties of the resulting nanocomposites such as roughness, textural porosity, or hydrophobicity, which furthermore affect their potential applications as catalysts supports, adsorbents, fillers, etc.

This current research may be a part of work on preparation of active biocatalyst composed with the functional support and biomolecules-e.g., enzymes.

Recently, many studies have been devoted to the immobilization of enzymatically active substances on inorganic, e.g., silica-based, supports towards heterogeneous biocatalyst preparation. This is especially related to the nature of such systems-their availability and relatively low cost as well as high mechanical strength and durability of biocatalyst granules in the reaction media $[26,27]$. In particular, lipases are the most widely used biomolecules in enzyme technology because of their widespecificity for some substrates, low production cost, wide $\mathrm{pH}$ activity profiles, as well as ability to catalyze various different reactions, such as hydrolysis, esterification, amination, transesterification, alcoholysis, etc. [28-30]. Graphene oxide (GO), having a large surface area $\left(2630 \mathrm{~m}^{2} / \mathrm{g}\right)$ and abundant functional groups (such as epoxide, hydroxyl, and carboxylic groups), provides a great substrate for enzyme immobilization without any surface modification or any coupling agents [31]. Nevertheless, among the various nanostructured materials that might be used as novel supports for enzyme immobilization and stabilization, CNTs are of great interest to many research centers worldwide due to their stability, high adsorption capacity, improvedretention of catalytic activity, and biocompatibility [32-35]. Both SWCNTs and MWCNTs have been used to immobilize enzymes [36]. MWCNTs are structurally similar to SWCNTs, but their diameters can range from a few nanometers to dozens of nanometers [37]. SWCNTs are attractive due to their larger surface area for protein interaction, excellent biocompatibility, antifouling properties, and high conductivity, but MWNTs are desirable because they are easier to prepare, exhibit better dispersibility, and are commercially available at a relative lower price, which makes them more feasible for industrial applications. Therefore, MWNTs are suitable materials as enzyme supports [38]. Enzymes can be immobilized on the surface of MWCNTs by adsorption or covalent binding, whichresultsin enhanced catalytic performance and stability. Moreover, lipases are well-known interfacially active catalysts and exhibit their catalytic abilities at the interface between the organic phase containing hydrophobic substrates and aqueous phase, so they can be activated at the hydrophobic-hydrophilic interface [34,39].

Herein, in the present work, for the first time, the methodology to design and characterize an alternative, highly stable, and active nanobiocatalyst based on Candida antarctica lipase B (CALB) immobilized onto pristine and poly(dimethylsiloxane)modified MWCNTsis presented and discussed. The idea was to combine the textural properties as well as functionality of PDMS modified with lipase activity, and to obtain a novel type of biocatalyst dedicated to biotechnological applications. As a result, high enzyme loading, its improved stability and reusability, as well as activity of the biocatalyst produced, were expected. The innovative nature of the presented study is based not only on application of a novel, previously undescribed support material for lipase immobilization, but also on the possibility to use MWCNT surface modifying agents at various molecular weights to examine their effects on enzyme loading and catalytic activity. 


\section{Materials and Methods}

\subsection{Chemicals and Materials}

Commercial poly (dimethylsiloxane) fluids of two molecular weights (Wacker Chemie $\mathrm{AG}$, linear, $-\mathrm{CH}_{3}$ terminated, code names: PDMS-100 and PDMS-12500 with $\mathrm{MW} \approx 3410$ and 39,500 g/mol, respectively) and multi-walled carbon nanotubes (MWCNTs, obtained by catalytic chemical vapor deposition (CCVD) [40] using pyrolysis of propylene on complex metal oxide catalysts) [41] were used as initialmaterials forpolymer nanocompositepreparation.

Candida antarctica lipase B (CALB) (EC 3.1.1.3, 200 U/g), para-nitrophenyl palmitate (p-NPP), para-nitrophenol (p-NP), gum arabic and Triton X-100 (laboratory grade), sodium hydroxide, sodium chloride, $50 \mathrm{mM}$ acetate buffer ( $\mathrm{pH} 3-5), 50 \mathrm{mM}$ phosphate buffer ( $\mathrm{pH}$ 6-8), and $50 \mathrm{mM}$ Tris- $\mathrm{HCl}$ ( $\mathrm{pH} 8$ and 9) were supplied from Sigma-Aldrich (St. Louis, MO, USA). All of the reagents were of analytical grade and were used directly without any further purification.

\subsection{Preparation of $M W C N T s / P D M S$ Nanocomposites}

PDMS-100 and PDMS-12500 fluids were physically adsorbed onto pristine multiwalled carbon nanotubes (P-MWCNTs) in the amount of $40 \mathrm{wt} . \%$. Before adsorption, the samples were dried at $110{ }^{\circ} \mathrm{C}$ for $2 \mathrm{~h}$. A hexane solution of PDMS (1 wt.\% PDMS) was prepared, and its estimated amount wasadded to a fixed amount of dry carbon powder material. The suspension was mechanically stirred and finally dried at room temperature for $48 \mathrm{~h}$ and then at $80{ }^{\circ} \mathrm{C}$ for $3 \mathrm{~h}$. All samples modified with PDMS in the amount of $40 \mathrm{wt} . \%$ were in the form of powder similar to P-MWCNTs, while neat PDMS-100 and PDMS-12500 were liquids. The prepared polymer nanocomposites were marked as MWCNTs/PDMS-100(40) and MWCNTs/PDMS-12500(40), respectively.

\subsection{Lipase Immobilization}

The pristine MWCNTs and MWCNTs/PDMS nanocomposites were used as supports for the immobilization of Candida antarctica lipase B (CALB). In all experiments, $100 \mathrm{mg}$ of P-MWCNTs or modified MWCNTs (MWCNTs/PDMS-100(40) and MWCNTs/PDMS$12500(40)$ ) were added to $5 \mathrm{~mL}$ of lipase solution at concentration of $5 \mathrm{mg} / \mathrm{mL}$ in $50 \mathrm{mM}$ phosphate buffer solution at $\mathrm{pH}$ 7. The samples were then shaken for $24 \mathrm{~h}$ using a KS 4000i Control incubator (IKA Werke GmbH, Staufen im Breisgau, Germany) at ambient temperature. Next, samples were centrifuged $\left(4000 \mathrm{rpm}\right.$ at $\left.4{ }^{\circ} \mathrm{C}\right)$ using an Eppendorf 5810 $\mathrm{R}$ centrifuge (Hamburg, Germany) and furthermore washed several times with $50 \mathrm{mM}$ phosphate buffer in order to remove unbounded lipase. The samples were labelled as CALB@P-MWCNTs, CALB@MWCNTs/PDMS-100(40), and CALB@MWCNTs/PDMS12500(40), respectively.

\subsection{Analysis of Nanocomposites before Lipase Immobilization \\ 2.4.1. Textural Characterization}

To analyze the textural characteristics of P-MWCNTs and MWCNTs/PDMS nanocomposites, low-temperature $(77.4 \mathrm{~K})$ nitrogen adsorption-desorption isotherms were recorded using an automatic gas adsorption analyzer ASAP 2420 (Micromeritics Instrument Corp., Norcross, GA, USA). Beforehand, the measurement samples were degassed at $110{ }^{\circ} \mathrm{C}$ for $2 \mathrm{~h}$ in a vacuum chamber. The values of surface area $\left(S_{\mathrm{BET}}\right)$ were calculated according to the standard BET method (using Micromeritics software). The total pore volume, $V_{p}$, was evaluated from the nitrogen adsorption at $p / p_{0}=0.98-0.99$ ( $p$ and $p_{0}$ denote the equilibrium and saturation pressure of nitrogen at $77.4 \mathrm{~K}$, respectively). The nitrogen desorption data were used to compute the pore size distributions (PSD, differential $f_{\mathrm{V}}(\mathrm{R}) \sim \mathrm{d} V \mathrm{p} / \mathrm{d} R$ and $\left.f_{\mathrm{S}}(\mathrm{R}) \sim \mathrm{d} S / \mathrm{d} R\right)$ ), using a model with slit-shaped and cylindrical pores and voids between spherical nanoparticles (SCV) with a self-consistent regularization (SCR) procedure for MWCNTs/PDMS samples and slit-shaped pores for P-MWCNTs [42,43]. The differential PSD with respect to pore volume $f_{\mathrm{V}} \sim \mathrm{d} V / \mathrm{d} R, \int f_{\mathrm{V}} \mathrm{d} R \sim V_{\mathrm{p}}$ were re-calculated to incre- 
mental PSD (IPSD) at $\phi_{\mathrm{V}}\left(R_{i}\right)=\left(f_{\mathrm{V}}\left(R_{i+1}\right)+f_{\mathrm{V}}\left(R_{i}\right)\right)\left(R_{i+1}-R_{i}\right) / 2$ at $\left.\sum \phi_{\mathrm{V}}\left(R_{i}\right)=V_{\mathrm{p}}\right)$. The $f_{\mathrm{V}}$ and $f_{\mathrm{S}}$ functions were also used to calculate contributions of micropores $\left(V_{\text {micro }}\right.$ and $S_{\text {micro }}$ at radius $R \leq 1 \mathrm{~nm}$ ), mesopores $\left(V_{\text {meso }}\right.$ and $S_{\text {meso }}$ at $1 \mathrm{~nm}<R<25 \mathrm{~nm}$ ), and macropores ( $V_{\text {macro }}$ and $S_{\text {macro }}$ at $25 \mathrm{~nm}<R<100 \mathrm{~nm}$ ) to the total pore volume and surface area.

\subsubsection{Spectral Analysis}

The Raman spectra were recorded over the $3200-500 \mathrm{~cm}^{-1}$ range using the in Via Reflex Microscope DMLM Leica Research Grade, Reflex (Renishaw, Wotton-under-Edge, $\mathrm{UK})$ with $\mathrm{Ar}^{+}$ion laser excitation at $\lambda_{0}=514.5 \mathrm{~nm}$. For each sample, the spectra were recorded at several points in order to ascertain the homogeneity of the sample, and the average results were plotted. The surface functional groups of the pristine MWCNTs and MWCNTs/PDMS nanocomposites, before and after lipase immobilization, were investigated using Fourier transform infrared spectroscopy (FTIR) in attenuated total reflectance (ATR) mode (Vertex 70 spectrometer, Bruker, Germany). The FTIR spectra were recordedat a wavenumber range of $4000-500 \mathrm{~cm}^{-1}$, and at a resolution of $1 \mathrm{~cm}^{-1}$.

\subsection{Characterization of Free and Immobilized Lipase}

The activity of free and immobilized lipase was estimated based on the model reaction of p-nitrophenyl palmitate hydrolysis to p-nitrophenol. The spectrophotometric measurements at $410 \mathrm{~nm}$, using a Jasco V-750 UV-Vis spectrophotometer (Jasco, Tokyo, Japan), were used for this purpose. In the reaction, $10 \mathrm{mg}$ of free lipase and a corresponding amount of the biocatalytic system produced (CALB@MWCNTs, CALB@MWCNTs/PDMS-100(40) and CALB@MWCNTs/PDMS-12500(40)), containing $10 \mathrm{mg}$ of the enzyme, were used. Reactions were carried out for $2 \mathrm{~min}$ under continuous stirring ( $800 \mathrm{rpm}$ ). After the assumedtime, the reaction was terminated, and absorbance was measured. The activity of the free and immobilized lipase was calculated using a standard calibration curve for $\mathrm{p}-\mathrm{NP}$. The amount of biocatalyst that hydrolyzed $1 \mu \mathrm{mol}$ of $\mathrm{p}-\mathrm{NPP}$ per minute was defined as the one unit of lipase activity. The highest measured activity was defined as $100 \%$ relative activity. The effect of $\mathrm{pH}$ on the activity of the free and immobilized lipase was determined based on the above-mentioned reaction at a temperature of $30^{\circ} \mathrm{C}$, in the $\mathrm{pH}$ range $3-11$, using buffer solution at the desired $\mathrm{pH}$. The effect of temperature on the activity of the free and immobilized lipase was determined according to the above-presented methodology at $\mathrm{pH} 7$ (50 $\mathrm{mM}$ phosphate buffer), over a temperature rangefrom 10 to $80^{\circ} \mathrm{C}$. All measurements were made in triplicate; error bars are presented as means \pm standard deviation.

\subsection{Stability and Reusability of Free and Immobilized Lipase}

Thermal stability over time was determined during incubation of free and immobilized enzyme for $180 \mathrm{~min}$ under optimal process conditions $\left(30^{\circ} \mathrm{C}\right.$ and $\left.\mathrm{pH} 7\right)$. The relative activity of free and immobilized lipase was further determined based on the model hydrolysis reaction of p-nitrophenyl palmitateat every specified period of time, applying spectrophotometric measurements at $410 \mathrm{~nm}$. The initial lipase activity was defined as $100 \%$ relative activity. The inactivation constant $\left(k_{D}\right)$ and enzyme half-life $\left(t_{1 / 2}\right)$ were determined based on the linear regression slope.

Storage stability of free lipase and products after immobilization were examined based on the above-mentioned model reaction of p-NPP hydrolysis over 30 days of storage at $4{ }^{\circ} \mathrm{C}$ in $50 \mathrm{mM}$ phosphate buffer at $\mathrm{pH}$ 7. The relative activity was measured every 2 days.

The reusability of the produced biocatalytic systems was also determined using the same model hydrolysis reaction carried out under optimal process conditions, over 10 repeated catalytic cycles. Immobilized lipase was separated from the reaction mixture by centrifugation, washed several timeswith $50 \mathrm{mM}$ phosphate buffer at $\mathrm{pH} 7$, and placed in the fresh substrate solution.

The effect of $5 \%$ Triton X-100 and $0.5 \mathrm{M} \mathrm{NaCl}$ on relative activity of the immobilized enzyme was examined over $24 \mathrm{~h}$ of incubation in a proper solution. After a specified period of time, the relative activity of the immobilized lipase was determined based on the model 
reaction of p-NPP hydrolysis. All measurements were made in triplicate; error bars are presented as means \pm standard deviation.

\section{Results}

\subsection{Analysis of Nanocomposites before Lipase Immobilization}

3.1.1. Parameters of the Porous Structure

The structural characteristic of P-MWCNTs and MWCNTs/PDMS nanocomposites wasstudied using low-temperature nitrogen adsorption-desorption isotherms (Figure 1a and Table 1). All of the materials were characterized withthe nitrogen adsorption isotherms of type II (H3 type of hysteresis loops) according to the IUPAC classification [44,45]. Capillary condensation occurred at pressure $p / p_{0}>0.85$ (due to adsorption in broad mesopores and macropores).

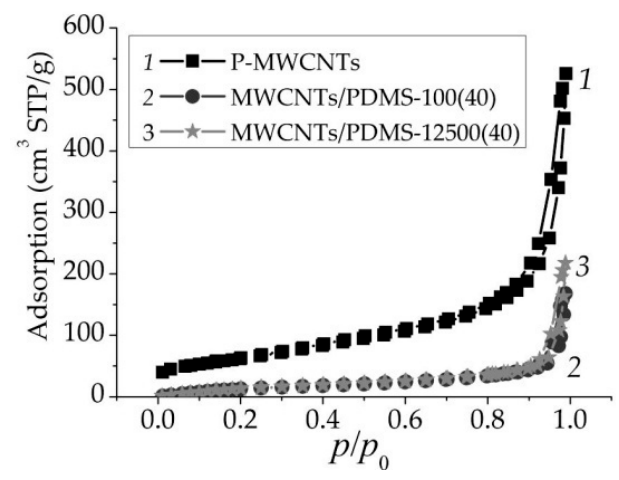

(a)

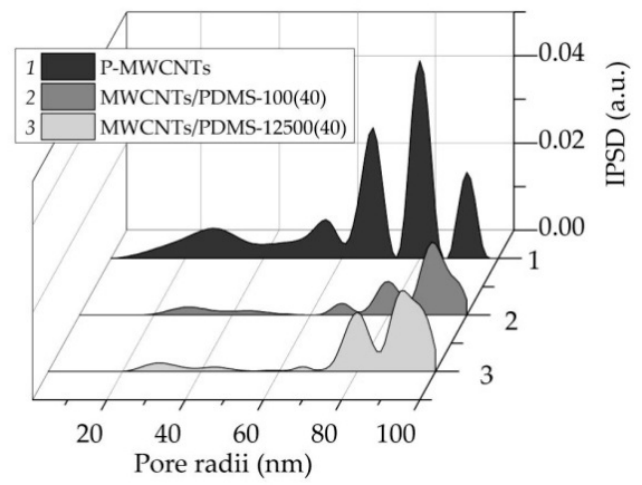

(b)

Figure 1. (a) Nitrogen adsorption-desorption isotherms and (b) incremental pore size distributions for P-MWCNTs (curve 1) and MWCNTs/PDMS nanocomposites (curves 2, 3).

Table 1. Textural characteristics of P-MWCNTs and MWCNTs/PDMS nanocomposites.

\begin{tabular}{|c|c|c|c|c|c|c|c|c|c|}
\hline Sample & $\begin{array}{c}S_{\mathrm{BET}} \\
\left(\mathrm{m}^{2} / \mathrm{g}\right)\end{array}$ & $\begin{array}{l}S_{\text {micro }} \\
\left(\mathrm{m}^{2} / \mathrm{g}\right)\end{array}$ & $\begin{array}{l}S_{\text {meso }} \\
\left(\mathrm{m}^{2} / \mathrm{g}\right)\end{array}$ & $\begin{array}{l}S_{\text {macro }} \\
\left(\mathrm{m}^{2} / \mathrm{g}\right)\end{array}$ & $\begin{array}{l}V_{\text {micro }} \\
\left(\mathrm{cm}^{3} / \mathrm{g}\right)\end{array}$ & $\begin{array}{c}V_{\text {meso }} \\
\left(\mathrm{cm}^{3} / \mathrm{g}\right)\end{array}$ & $\begin{array}{l}V_{\text {macro }} \\
\left(\mathrm{cm}^{3} / \mathrm{g}\right)\end{array}$ & $\begin{array}{c}V_{\mathrm{p}} \\
\left(\mathrm{cm}^{3} / \mathrm{g}\right)\end{array}$ & $\begin{array}{l}R_{p, V} \\
(\mathbf{n m})\end{array}$ \\
\hline P-MWCNTs & 222 & 74 & 134 & 14 & 0.039 & 0.418 & 0.357 & 0.814 & 23 \\
\hline $\begin{array}{c}\text { MWCNTs/PDMS- } \\
100(40)\end{array}$ & 76 & 0 & 56 & 20 & 0 & 0.056 & 0.203 & 0.259 & 62 \\
\hline $\begin{array}{c}\text { MWCNTs/PDMS- } \\
12500(40)\end{array}$ & 77 & 0 & 51 & 26 & 0 & 0.054 & 0.283 & 0.337 & 65 \\
\hline
\end{tabular}

Surface area values (Table $1, S_{\mathrm{BET}}$ ) demonstrated a significant reduction after adsorption of both types of PDMS onto carbon nanotube surfaces. Moreover, the total pore volume $\left(V_{\mathrm{p}}\right)$ decreased for the MWCNTs/PDMS-100 and MWCNTs/PDMS-12500 nanocomposites by 68 and 59\%, respectively, as compared to the P-MWCNTs. Moreover, it was observed that the pore average radii in MWCNTs/PDMS $(-100,-12,500)$ samples was three times greater than that of P-MWCNTs.

The incremental pore size distribution IPSD functions (Figure 1b) show that the textural characteristics ofMWCNTschanged after the modification with polymer. The textural porosity of the pristine MWCNT resulted from mesopores and secondly due to micropore presence. MWCNTs/PDMS nanocomposites were characterized by bimodal porous structures (Figure 1b). In addition, MWCNTs/PDMS samples were characterized with a significant decrease in mesopore contributions to the total porosity with a simultaneous increase in contributions of macropores as compared to P-MWCNTs. 


\subsubsection{Raman Spectroscopy}

Raman spectroscopy is a very valuable tool for the characterization of carbon-based nanostructures. This technique is used to analyze the presence of amorphous and crystalline phases corresponding to differences in graphitization. The spectra were collected in the most informative range for carbon materials of $3200-500 \mathrm{~cm}^{-1}$ (Figure 2). Three major peaks at $1341 \mathrm{~cm}^{-1}$ as the D-band ( $\mathrm{sp}^{3}$ carbons in non-graphitic structures), at $1570 \mathrm{~cm}^{-1}$ as the G-band ( $\mathrm{sp}^{2}$ carbons in graphitic structures), and its second-order harmonic at $2672 \mathrm{~cm}^{-1}$ as the $\mathrm{G}^{\prime}$-band, were noted [46]. The ratio between the integral intensities of the $G$ and $D$ bands $\left(A_{G} / A_{D}\right.$ ratio as a measure of the graphitization degree) is an indicator of the crystallinity degree [47]. The value of $A_{G} / A_{D}$ was calculated by deconvolution of the spectra using the Lorentzian function. After adsorption of polymer, relative intensity ratio $A_{G} / A_{D}$ tended to decrease from 1.1 for P-MWCNTs to 0.95 for MWCNTs/PDMS nanocomposites, respectively.

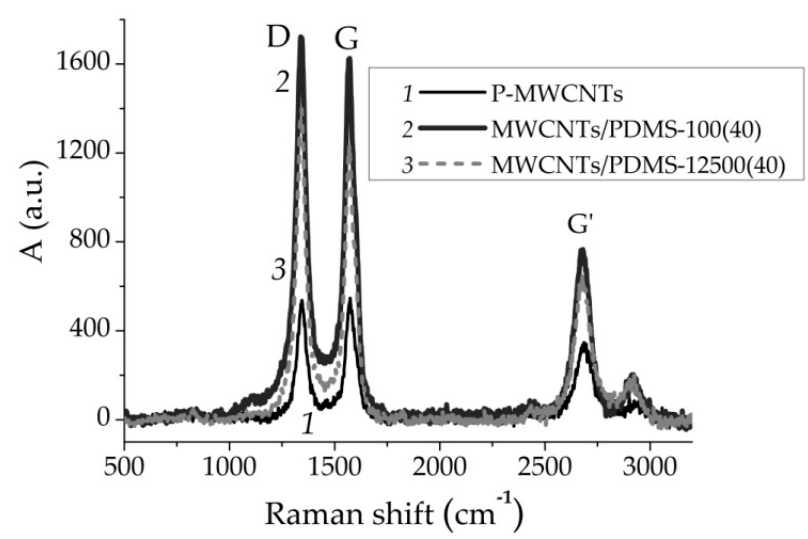

Figure 2. Raman spectra for P-MWCNTs (curve 1) and MWCNTs/PDMS nanocomposites (curves 2, 3).

\subsubsection{ATR-FTIR Spectroscopy}

Fourier transform infrared spectroscopy was used to determine the nature of chemical groups present on the surface of analyzed materials as well as to indirectly confirm nanotube modification and enzyme immobilization (Figure 3).

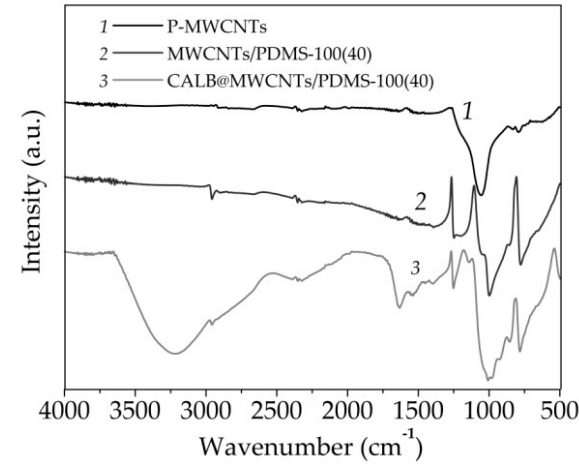

(a)

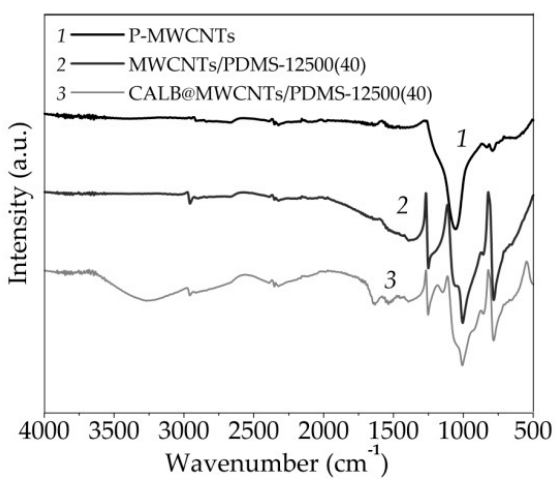

(b)

Figure 3. FTIR spectra of (a) P-MWCNTs, MWCNTs/PDMS-100, and (b) MWCNTs/PDMS-12500 nanocomposites, before and after lipase immobilization.

The FTIR spectrum of the P-MWCNTs showeda broad peak with a maximum at $1060 \mathrm{~cm}^{-1}$ that corresponded to the stretching vibrations of $\mathrm{C}-\mathrm{O}$ bonds in carboxylic groups present onto the surface of MWCNTs. Upon modification by PDMS, irrespectively of the molecular mass of the modifying agent used, additional signals could be observed. The small signal at $2950 \mathrm{~cm}^{-1}$ was related to the presence of $\mathrm{C}-\mathrm{H}$ stretching vibrations, 
peaks at 1250 and $780 \mathrm{~cm}^{-1}$ corresponded to the stretching and bending vibrations of $\mathrm{Si}-\mathrm{CH}_{3}$ groups, whereas peaks at 1010 and $1055 \mathrm{~cm}^{-1}$ were characteristic for the stretching vibrations of $\mathrm{Si}-\mathrm{O}-\mathrm{Si}$ bonds [48]. After enzyme immobilization onto both materials, the presence of additional signals, characteristic for the enzyme structure, was clearly seen. Among them, the most important was a peak at $3400 \mathrm{~cm}^{-1}$, assigned to the stretching vibrations of $-\mathrm{OH}$ groups, and two signals at 1655 and $1545 \mathrm{~cm}^{-1}$, ascribed to the stretching vibrations of amide I and amide II bands, respectively. Further, it could be seen that the intensity of signals characteristic for enzyme was higher in the CALB@MWCNTs/PDMS100(40) spectrum, as compared to the CALB@MWCNTs/PDMS-12500(40) spectrum.

\subsection{Characterization of Free and Immobilized Lipase}

The next stage included tests of obtained materials (MWCNTs modified with $40 \mathrm{wt} . \%$ of PDMS-100 and PDMS-12500) as supports for enzyme immobilization. Lipase was selected as a model enzyme, as itexhibitsimproved catalytic activity in a hydrophobic microenvironment. The effect of various process conditions on thestability and activity of the immobilized enzyme was determined, and the reusability of the produced biocatalytic systems was examined.

\subsection{1. $\mathrm{pH}$ Profiles of Free and Immobilized Lipase}

Free lipase and biocatalytic systems produced showed maximum activity at $\mathrm{pH} 7$ (Figure 4). Further, their $\mathrm{pH}$ profiles weresimilar. In the tested $\mathrm{pH}$ range (beside $\mathrm{pH} 7$ ), free enzyme exhibited relative activity not higher than $60 \%$ and even less than $30 \%$ at $\mathrm{pH}$ ranges from 3 to 5 and from 9 to 11. By contrast, enzyme immobilized on both pristine and modified MWCNTs showed about 10-30\% higher relative activity over whole analyzed $\mathrm{pH}$ range. Further, lipase deposited onto MWCNTs/PDMS nanocomposites retained over $80 \%$ of its relative activity over a wide $\mathrm{pH}$ rangefrom 6 to 9 and more than $30 \%$ relative activity at $\mathrm{pH} 3$ to 10. It should also be highlighted that lipase immobilized onto MWCNTs/PDMS100(40) material exhibited around 5-10\% higher activity than enzyme immobilized onto carbon nanotubes functionalized by PDMS withhigher molecular weight.

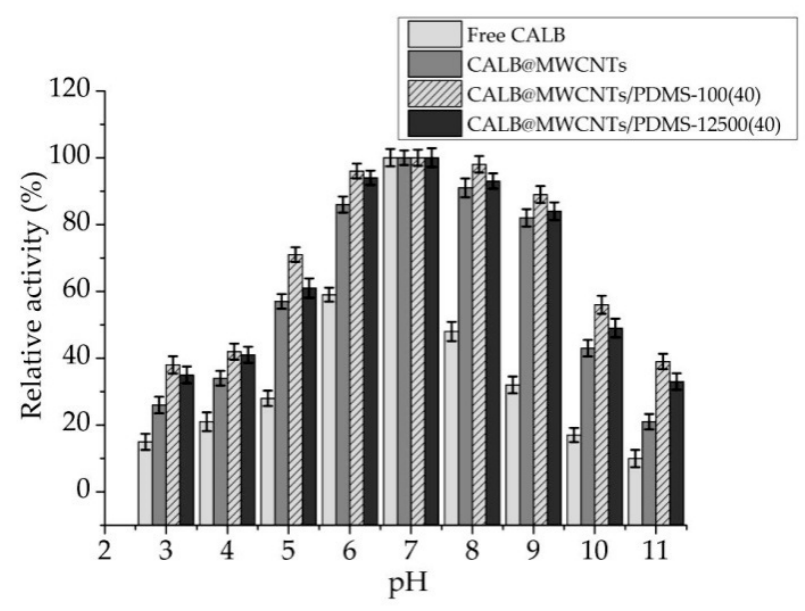

Figure 4. $\mathrm{pH}$ profiles of free lipase and enzymeimmobilized onto P-MWCNTs and MWCNTs/ PDMS nanocomposites.

\subsubsection{Temperature Profiles of Free and Immobilized Lipase}

Temperature profiles of free and immobilized lipase were determined over a temperature range of $10-80^{\circ} \mathrm{C}$ (Figure 5). The optimal temperature for all analyzed samples was found to be $30^{\circ} \mathrm{C}$. Even a slight change in temperature conditions resulted in a sharp decrease of catalytic activity of free enzyme. Only at temperatures ranging from 20 to $40{ }^{\circ} \mathrm{C}$ did free lipase show over $60 \%$ of relative activity. Although temperature profiles of immobilized biomolecules exhibited similarity in shape to those of free enzyme, sig- 
nificantly higher relative activityof those systems was observed over the whole analyzed temperature range. At temperatures ranging from 20 to $70{ }^{\circ} \mathrm{C}$, over $60 \%$ of relative activity was noticed for all analyzed biocatalytic systems. Finally, similarly as analyzing $\mathrm{pH}$ effect on relative activity of immobilized lipase, slightly higher activity was noticed when MWCNTs/PDMS-100(40) material was used as support for enzyme immobilization.

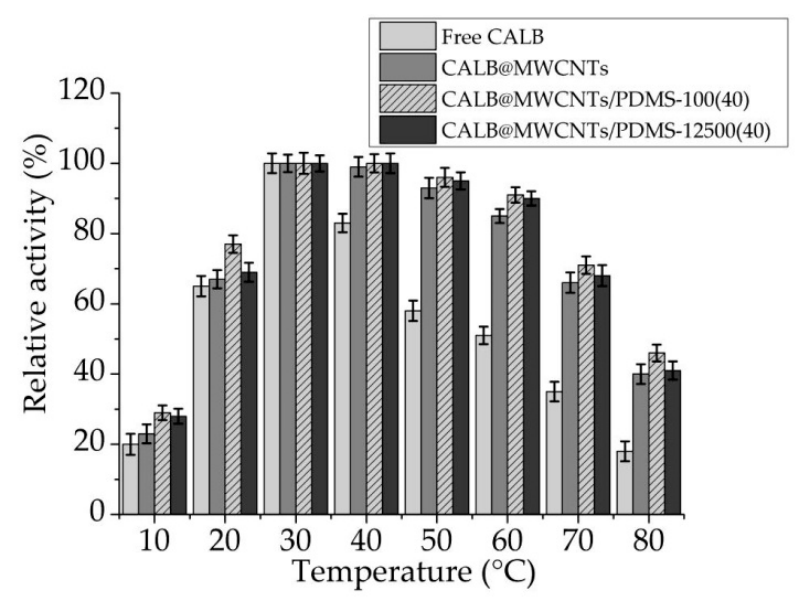

Figure 5. Temperature profiles of free lipase and enzyme immobilized onto P-MWCNTs and MWCNTs/PDMS nanocomposites.

\subsubsection{Thermal Stability of Free and Immobilized Lipase}

Thermal stability of free and immobilized lipase was determined via samples incubation for $3 \mathrm{~h}$ at a temperature of $30^{\circ} \mathrm{C}$ and atpH 7 (Figure 6). A relative activity decrease over incubation time for free and immobilized lipase was observed. However, the drop of catalytic properties was more pronounced for free enzyme, which retained less than $20 \%$ of its relative activity after $3 \mathrm{~h}$ of incubation. Significantly higher values of relative activity were noticed for biocatalytic systems produced. The decrease of catalytic activity of immobilized lipase was much slower as compared to the free counterpart; after $1 \mathrm{~h}$ and $3 \mathrm{~h}$ of incubation, immobilized enzyme showed around $40 \%$ and $50 \%$ higher values of relative activity, respectively. Finally, both biocatalytic systems obtained using MWCNTs/PDMS nanocomposites showed relative activity exceeding $80 \%$ after specific incubation periods.

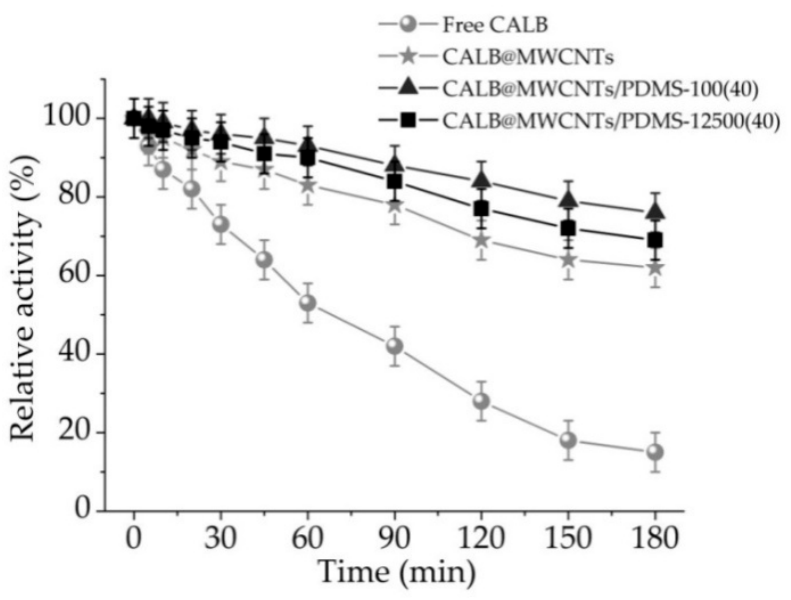

Figure 6. Thermal stability of free lipase and enzyme immobilized onto P-MWCNTs and MWCNTs/PDMS nanocomposites.

In order to clearly present improvement of lipase stability and activity upon immobilization, enzyme inactivation constant $\left(k_{D}\right)$ and enzyme half-life $\left(t_{1 / 2}\right)$ were determined 
(Table 2). These parameters were calculated based on the linear regression slope from the above-presented Figure 6 . Free lipase was characterized by $k_{D}=0.01075 \mathrm{~min}^{-1}$ and a half-life of $64.74 \mathrm{~min}$. Inactivation constant and enzyme half-life of immobilized lipase were improved. The most predominant increase of enzyme stability was noticed for lipase immobilized onto MWCNT/PDMS-100(40) material. Over a seven-fold lower inactivation constant $\left(0.00126 \mathrm{~min}^{-1}\right)$ and consequently over a seven-fold higher enzyme half-life (446.15 $\mathrm{min}$ ) were observed for this particular biocatalytic system.

Table 2. Inactivation constant and half-life of free lipase and enzyme immobilized onto P-MWCNTs and MWCNTs/ PDMS nanocomposites.

\begin{tabular}{ccccc}
\hline Parameter & Free CALB & CALB@P-MWCNTs & $\begin{array}{c}\text { CALB@MWCNTs/ } \\
\text { PDMS-100(40) }\end{array}$ & $\begin{array}{c}\text { CALB@MWCNTs/ } \\
\text { PDMS-12500(40) }\end{array}$ \\
\hline$k_{D}\left(\mathrm{~min}^{-1}\right)$ & 0.01075 & 0.00268 & 0.00156 & 0.00208 \\
$t_{1 / 2}(\mathrm{~min})$ & 64.74 & 259.70 & 446.15 & 334.61 \\
\hline
\end{tabular}

\subsubsection{Storage Stability and Reusability of Free and Immobilized Lipase}

From apractical application point of view, storage stability and reusability are the crucial properties determining possible large-scale use of the immobilized enzymes. In this study storage stability of free and immobilized lipase was followed over 30 days, and reusability potential was examined over ten repeated reaction cycles (Figure 7).

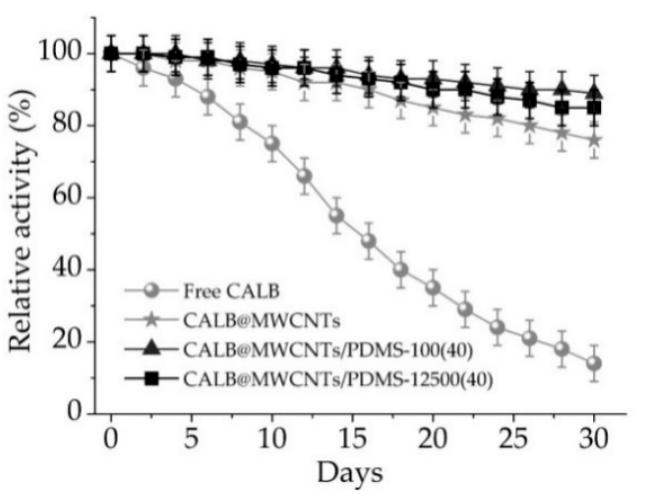

(a)



(b)

Figure 7. (a) Storage stability and (b) reusability of free lipase and enzyme immobilized onto P-MWCNTs and MWCNTs/PDMS nanocomposites.

It can be seen (Figure 7a) that storage stability of the lipase gradually decreased from the first day of storage; after 30 days it reached less than $20 \%$. By contrast, storage stability of all tested biocatalytic systems with immobilized enzyme was improved significantly. Obtained biocatalytic systems showed over $90 \%$ relative activity after 6 days of storage and over $80 \%$ after 30 days. Further, lipase immobilized onto MWCNTs/PDMS nanocomposites showed over $90 \%$ activity retention at the end of the test.

Results of the reusability study (Figure $7 \mathrm{~b}$ ) showed that relative activity of the lipase immobilized onto MWCNTs/PDMS nanocomposites and P-MWCNTs remained almost unaltered for the first three reaction steps. Over the next experimental steps, catalytic activity decreased slightly. After ten cycles, relative activity of lipase immobilized onto P-MWCNTs reached 85\%, whereas activity of lipase immobilized onto MWCNTs/PDMS nanocompositesattained over $90 \%$. 


\subsubsection{Effect of Solvents on the Immobilized Lipase}

The effects of surfactant (Triton X-100) and salt solution $(0.5 \mathrm{M} \mathrm{NaCl})$ on catalytic activity of immobilized enzymes and stability of enzyme binding were determined by incubation of produced biocatalytic systems in the presence of the mentioned solutions over time. In Figure 8, it can be seen that relative activity of immobilized enzymes decreased gradually over first $6 \mathrm{~h}$ of incubation. After that time, all biocatalytic systems showed less than $50 \%$ and less than $30 \%$ of relative activity in the presence of Triton X-100 and $\mathrm{NaCl}$, respectively. Further treatment of the biocatalysts withthe solvents did not result in such a pronounced drop in relative activity. After $24 \mathrm{~h}$ of incubation of lipase immobilized onto MWCNTs/PDMS nanocompositesin Triton X-100 and NaCl solution, analyzed samples retained over $40 \%$ and over $20 \%$ of relative activity, respectively.

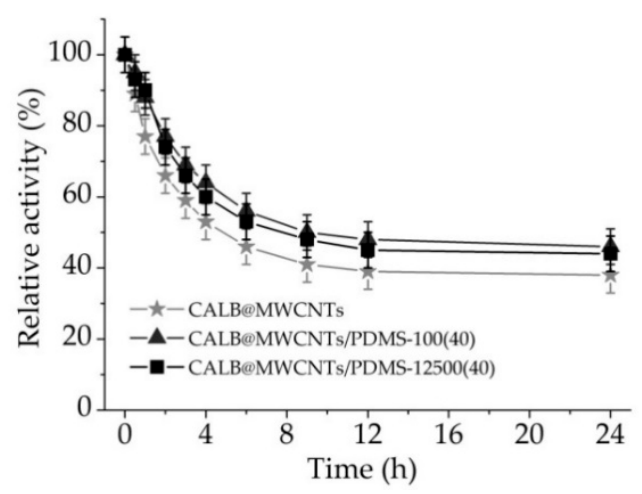

(a)

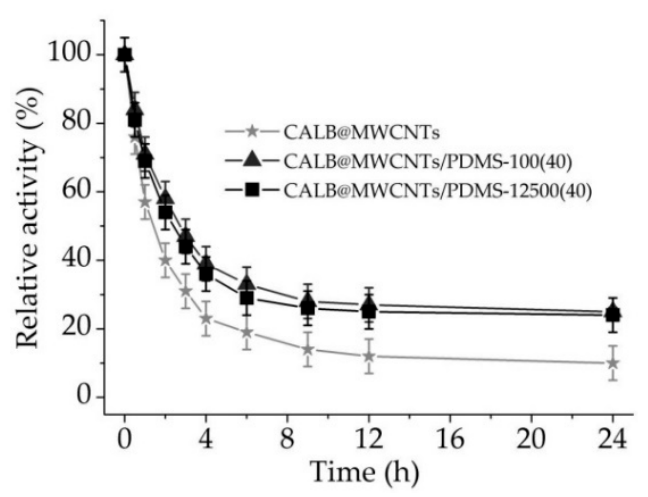

(b)

Figure 8. Effect of (a) $5 \%$ Triton X-100 solution and (b) $0.5 \mathrm{M} \mathrm{NaCl}$ solution on the relative activity of lipase immobilized onto P-MWCNTs and MWCNTs/PDMS nanocomposites.

\section{Discussion}

\subsection{Analysis of Nanocomposites before Lipase Immobilization}

The presented results demonstrate the changes in the textural/structural properties of MWCNTs after modification with polymer. The obtained data can be discussed also in terms of the absolute values of the surface area, $S_{\mathrm{BET}}$, which sharply decreased from $222 \mathrm{~m}^{2} / \mathrm{g}$ to $76-77 \mathrm{~m}^{2} / \mathrm{g}$ after PDMS $(-100,-12,500)$ grafting (in the amount of $40 \mathrm{wt} . \%$ ) onto carbon nanotube surfaces. That can be explained by two factors: reducing the content of MWCNTs in the resulting polymer composites after PDMS modification, as carbon nanotubes are responsible forsurface area, as well as increasing the size (diameter) of MWCNTs due to the polymer grafting onto carbon nanotubes. It is known that surface area is inversely proportional to the particle size of the dispersed phase. In general, the polymer adsorption leads to suppression of the values of $V_{\mathrm{p}}, V_{\text {meso }}$, and $V_{\text {macro }}$ because each long PDMS macromolecule can bind carbon nanotubes and aggregate themin more compacted structures, whichleads to adecrease in the volume of voids between MWCNTs [49].

It was found that the prepared nanocomposites are characterized by different graphitization degrees according to the data of Raman spectroscopy. A relatively lower $A_{G} / A_{D}$ ratio (about 0.9 ) for polymer nanocomposites indicates a low graphitization degree and shows that graphitic layers are semi-crystalline and possess many defects related to the $\mathrm{D}$ band due to introduction of new functional groups to carbon nanotube surfaces. The $G^{\prime}$ peak appears at $2672 \mathrm{~cm}^{-1}$ as an overtone of the $\mathrm{D}$ band and is believed to originate from finite-size disordered structures of graphite (i.e., with the $\mathrm{sp}^{2} \mathrm{C}$ atoms) in the surface layers of the nanocomposites [50]. It would be interesting to check in futurework the results obtained here with respect to other polymers and other carbon-based fillers.

The results of FTIR analysis confirmed the carbon structure of the P-MWCNTs and indicatedthe presence of carboxylic groups on their surface that facilitate further MWC- 
NTs modification. Upon PDMS adsorption onto MWCNTs, new signals are observed in the FTIR spectra of both modified samples, whichsuggests effective modification using poly(dimethylsiloxane) at various molecular weights. Nevertheless, the most important findings were made based on analysis of FTIR spectra of samples after lipase immobilization. The presence of signals characteristic for vibrations of amide I, amide II, and hydroxyl groups clearly indicate effective deposition of the enzyme onto the surface of both modified materials [51]. Moreover, the higher intensity of the signals ascribed for lipase structure, observed in FTIR spectrum of the system formed using MWCNTs modified with PDMS-100, indicate that a greater amount of the enzyme was immobilized, and immobilized biocatalysts retained higher catalytic properties [52].

\subsection{Immobilized Lipase Characterization}

Obtained data clearly showed that although $\mathrm{pH}$ and temperature profiles of free and immobilized lipase are similar, enzymes attached to P-MWCNTs and MWCNTs/PDMS nanocompositesshowed significantly higher relative activity over wider $\mathrm{pH}$ and temperature ranges as compared to free counterparts. Moreover, significant improvement of thermal stability and enzyme half-life of the lipase after immobilization was observed. A drop of the catalytic properties of the lipase in conditions different than optimal is related to the electrostatic repulsion of positively and negatively charged ionic groups in the enzyme structure and is also caused by thermal denaturation of the enzyme at harsh temperature conditions $[53,54]$. By contrast, immobilized lipase showed over $80 \%$ relative activity over wide $\mathrm{pH}(6-9)$ and temperature $\left(30-60^{\circ} \mathrm{C}\right)$ ranges. This might be explained by the fact that upon immobilization, an external backbone for the enzyme structure is provided due the formation of stable enzyme-support interactions, which stabilize enzyme structure and protect against biocatalyst denaturation at harsh reaction conditions [55]. Nevertheless, similarity in the $\mathrm{pH}$ and temperature profiles, and the presence of optima at the same conditions for free and immobilized lipases, as well asretention of high catalytic activity by produced systems indicate that immobilization did not significantly interfere with enzyme structure and its active site. It should be highlighted that among tested samples, the highest activity and tolerance to reaction conditions are ascribed to the lipase immobilized onto MWCNTs/PDMS-100(40) material. This is directly related to the fact that PDMS provides the hydrophobic nature of the surface and consequently the hydrophobic microenvironment for the immobilized lipase. In these conditions, lipase might undergo a phenomenon called interfacial activation, whichis based on opening of the polypeptide lid of the enzyme active site, leading to improvement of the activity of the immobilized enzyme [56,57]. Finally, significant enhancement of enzyme thermal stability (up to $50 \%$ higher relative activity, as compared to free enzyme) and reduction ofinactivation constant of immobilized enzymes are related to the fact that immobilization providesa protective environment for the enzyme molecules, whichreduces conformational changes of the enzyme structure in the presence of long-heat exposure. The advancement of using PDMS modified support for lipase immobilization was recently proved. Li et al. [58] modified silk fabric by amino-functional poly(dimethylsiloxane) (PDMS) and used it as a support for lipase from Candida sp. immobilization. It was shown that lipase activity and stability increased upon immobilization onto the hydrophobic surface. However, it was emphasized that the amount of the PDMS used affected catalytic properties of the immobilized enzyme. In another study, macroporous ZIF-8 was modified with PDMS in order to builda hydrophobic pore space for lipase from Aspergillus niger immobilization. Immobilized lipase showed improved stability and was found as an effective biocatalyst in the transesterification process in biodiesel production [59].

Determination of the storage stability and reusability of immobilized lipases is of crucial importance, as these parameters are key, determining possible practical application of the biocatalytic systemsproduced. All produced biocatalysts showed over $80 \%$ relative activity, even after 30 days of storage and 10 repeated uses, clearly indicating possible large-scale application. Such improvement of long-term stability and reusability is mainly 
related to the stabilization of the enzyme structure upon immobilization as well as the protective effects of both the MWCNTs support and the PDMS layer on the enzyme structure against inactivation over storage and reuse [60]. In the next part of the study, in order to determine the stability of the formed enzyme-support interactionsand the effects of various solvents on relative activity of immobilized enzymes, produced systems were incubated for $24 \mathrm{~h}$ in Triton X-100 and $\mathrm{NaCl}$ solutions. A significant drop in relative activity of immobilized lipase in the presence of both solvents might be explained mainly by two factors. Firstly, enzyme support interactions are based mainly on hydrogen and van der Waals interactions, which in the presence of Triton X-100 and $\mathrm{NaCl}$ lead to the partial elution of the enzyme from the support and decreased catalytic properties. Further, ionic strength might also affect catalytic properties of the immobilized enzyme by disturbing ionic interactions in the structure of the enzyme [61]. Partial elution of the enzyme and its inhibition by the reaction products are also explained by a slight decrease in the relative activity of the enzyme under repeated use. All of the above-mentioned facts negatively affect storage stability and reusability of the biocatalytic systems produced. Nevertheless, retention of over $80 \%$ activity after 30 days of storage, and 10 repeated catalytic cycles by the designed system, suggest that further study ofapplication of MWCNTs and PDMS modified MWCNTs as supportsfor enzyme immobilization are still required. In another study, Jamie et al. [62] immobilized lipase by covalent binding onto MWCNTs modified by n-2-hydroxysuccinimide/(1-ethyl-3-(3-dimethylaminopropyl)carbodiimide) (NHS/EDC) approach. Significant improvement of enzyme activity and operational stability was noticed, which is in agreement with the findings presented in this manuscript. Further, Khan et al. [63] immobilized lipase by adsorption onto MWCNTs treated with $\mathrm{NHO}_{3}$ and $\mathrm{H}_{2} \mathrm{SO}_{4}$. In this study, a protective effect of the support material was confirmed; however, it was highlighted that the initial concentration of the enzyme solution plays an important role in the final activity of immobilized lipase.

Recently, lipases of various origin were immobilized using a wide range of support materials, including sol-gel derived silica, zeolites, as well as synthetic polymers and biopolymers [64-68] (Table 3). In the presented studies, usually adsorption immobilization was applied resulting in production of biocatalytic systems characterized by retention of high catalytic activity and significant long-term stability and reusability. Further, application of obtained systems in hydrolysis reactions results in the attaining of over $90 \%$ process efficiency. In this context, lipase immobilized using biopolymers (modified chitin, spongin scaffolds), the application of which results in 100\% transesterification efficiency, seems to be of particular importance $[30,68]$. Presented in this study approach, where MWCNTs modified with PDMS were used, results in production of a highly active biocatalytic system that retained $94 \%$ of its catalytic activity and over $90 \%$ of activity after 20 days of storage and 10 repeated catalytic cycles. High long-term stability and recycle potential of the obtained systems facilitates their potential in real condition applications, for instance in biodiesel production or in the pharmaceutical industry. 
Table 3. Comparison of the most important parameters of lipase immobilized using various support materials. n.a.—not available.

\begin{tabular}{|c|c|c|c|c|c|c|c|}
\hline Enzyme & Support & $\begin{array}{c}\text { Type of } \\
\text { Immobilization }\end{array}$ & Reusability & Storage Stability & Activity Retention & Process Efficiency & Ref. \\
\hline $\begin{array}{c}\text { Lipase from } \\
\text { Rhizomucor miehei }\end{array}$ & Pure silica zeolites & Adsorption & $60 \%$ after 4 catalytic cycles & n.a. & $68 \%$ & $\begin{array}{l}93 \% \text { of methyl } \\
\text { myristate conversion }\end{array}$ & {$[64]$} \\
\hline $\begin{array}{c}\text { Fusarium solanipisi } \\
\text { recombinant cutinase with } \\
\text { high lipolytic activity }\end{array}$ & Zeolite & Adsorption & n.a. & $89 \%$ after 45 days & $74 \%$ & $\begin{array}{l}91 \% \text { of trycaprylin } \\
\text { transformation }\end{array}$ & [65] \\
\hline $\begin{array}{l}\text { Commercial lipases from } \\
\text { Rhizomucor miehei }\end{array}$ & Polypropylene & Adsorption & $85 \%$ after 8 catalytic cycles & n.a. & over $70 \%$ & $\begin{array}{l}90 \% \text { of sunflower oil } \\
\text { methanolysis }\end{array}$ & [66] \\
\hline $\begin{array}{c}\text { Lipase from } \\
\text { Rhizornucor rniehei }\end{array}$ & Sol-gel silica & Entrapment & n.a. & $75 \%$ after 20 days & $86 \%$ & n.a. & [67] \\
\hline $\begin{array}{l}\text { Lipase B from } \\
\text { Candida antarctica }\end{array}$ & $\begin{array}{l}\text { Hippospongiacommunis } \\
\text { spongin scaffolds }\end{array}$ & Adsorption & $82 \%$ after 20 catalytic cycles & $85 \%$ after 20 days & $91 \%$ & $\begin{array}{c}100 \% \text { of rapeseed oil } \\
\text { methanolysis }\end{array}$ & {$[30]$} \\
\hline $\begin{array}{l}\text { Lipase B from } \\
\text { Candida antarctica }\end{array}$ & $\begin{array}{l}\text { Chitin modified by } \\
\text { POSS * compounds }\end{array}$ & Adsorption & $87 \%$ after 15 catalytic cycles & $90 \%$ after 20 days & $87 \%$ & $\begin{array}{c}100 \% \text { of rapeseed oil } \\
\text { methanolysis }\end{array}$ & [68] \\
\hline $\begin{array}{l}\text { Lipase B from } \\
\text { Candida antarctica }\end{array}$ & $\begin{array}{l}\text { MWCNTs modified } \\
\text { by PDMS }\end{array}$ & Adsorption & $91 \%$ after 10 catalytic cycles & $90 \%$ after 20 days & $94 \%$ & n.a. & this study \\
\hline
\end{tabular}




\section{Conclusions}

In the presented study, the fabrication of highly stable and active biocatalysts based on Candida antarctica lipase B (CALB) immobilized onto pristine and modified MWCNTs by poly(dimethylsiloxane) was reported. During material characterization, it was proved that the textural characteristics ofMWCNTs change after the modification with polymer, and that the prepared nanocomposites are characterized by a different graphitization degree, which results from, e.g., surface modification of carbon nanotubes with polymer-a lower graphitization degree; graphitic layers are semi-crystalline and possess many defects related to the introduction of new functional groups to carbon nanotube surfaces. Effective MWCNTs with poly(dimethylsiloxane) as well as enzyme loading were confirmed by bands present on FTIR spectra, characteristic for both modifier and biomolecule structures, which all together confirmed relative high potential of synthesized MWCNTs-based materials as a support for lipase immobilization. Enzyme loaded onto P-MWCNTs and MWCNTs/PDMS nanocomposites showed significantly higher relative activity over wider $\mathrm{pH}$ and temperature ranges as compared to free counterparts. Moreover, significant improvement of thermal stability and enzyme half-life of the lipase after immobilization was observed. It was confirmed that after immobilization, the external backbone for the enzyme structure was provided due the formation of stable enzyme-support interactions, which stabilize the enzyme structure and protect against biocatalyst denaturation under harsh reaction conditions. This fact suggests wide application potential of designed novel types of biocatalytic systems in various technological/biotechnological applications.

Author Contributions: I.S. and J.Z. conceived and designed the experiments, analyzed and interpreted the data, and wrote the original draft of the manuscript. I.S. calculated the textural parameters for P-MWCNTs and nanocomposites using a self-consistent regularization procedure. D.S. and A.D.-M. participated in the measurement of Raman spectroscopy and the low-temperature nitrogen adsorption-desorption technique for nanocomposites. F.C. and T.J. supervised the work and performed the final reviewing and editing of the manuscript. All authors have read and agreed to the published version of the manuscript.

Funding: The authors acknowledge financial support by the Centre for East European Studies (University of Warsaw) within the framework of "NAGRODA im. I. WYHOWSKIEGO" supporting the scientific internship of I. Sulym at Poznan University of Technology and Maria Curie-Skłodowska University in Lublin (November 2018-May 2019). The financial support of the Visegrad Fund (Contract number 51910525) is greatly appreciated. This research was also partially supported by Ministry of Education and Science Poland.

Institutional Review Board Statement: Not applicable.

Informed Consent Statement: Not applicable.

Data Availability Statement: The datasets supporting the conclusions of this work are included within the article. Any raw data generated and/or analyzed in the present study are available from the corresponding author upon request.

Acknowledgments: The authors would like to express their gratitude to Yuri I. Sementsov (Chuiko Institute of Surface Chemistry, National Academy of Sciences of Ukraine, Kyiv, Ukraine) for providing the pristine MWCNTs.

Conflicts of Interest: The authors declare no conflict of interest.

\section{References}

1. Dresselhaus, M.S.; Jorio, A.; Hofmann, M.; Dresselhaus, G.; Saito, R. Perspectives on Carbon Nanotubes and Graphene Raman Spectroscopy. Nano Lett. 2010, 10, 751-758. [CrossRef]

2. Xu, T.; Yang, J.; Liu, J.; Fu, Q. Surface modification of multi-walled carbon nanotubes by $\mathrm{O}_{2}$ plasma. Appl. Surf. Sci. 2007, 253, 8945-8951. [CrossRef]

3. Yudianti, R. Analysis of Functional Group Sited on Multi-Wall Carbon Nanotube Surface. Open Mater. Sci. J. 2011, 5, $242-247$. [CrossRef]

4. Karousis, N.; Tsotsou, G.-E.; Evangelista, F.; Rudolf, P.; Ragoussis, N.; Tagmatarchis, N. Carbon Nanotubes Decorated with Palladium Nanoparticles: Synthesis, Characterization, and Catalytic Activity. J. Phys. Chem. C 2008, 112, 13463-13469. [CrossRef] 
5. Ciraci, S.; Dag, S.; Yildirim, T.; Gülseren, O.; Senger, R.T. Functionalized carbon nanotubes and device applications. J. Phys. Condens. Matter 2004, 16, R901-R960. [CrossRef]

6. Holger, F.; Bettinger, D. Carbon Nanotubes: Basic Concepts and Physical Properties; WILEY-VCH Verlag GmbH \& Co. KGaA: Weinheim, Germany, 2004.

7. Ibrahim, K.S. Carbon nanotubes-properties and applications: A review. Carbon Lett. 2013, 14, 131-144. [CrossRef]

8. Wepasnick, K.A.; Smith, B.A.; Bitter, J.L.; Fairbrother, D.H. Chemical and structural characterization of carbon nanotube surfaces. Anal. Bioanal. Chem. 2010, 396, 1003-1014. [CrossRef] [PubMed]

9. He, X.; Kitipornchai, S.; Wang, C.; Liew, K. Modeling of van der Waals force for infinitesimal deformation of multi-walled carbon nanotubes treated as cylindrical shells. Int. J. Solids Struct. 2005, 42, 6032-6047. [CrossRef]

10. Ebbesen, T.W.; Lezec, H.J.; Hiura, H.; Bennett, J.W.; Ghaemi, H.F.; Thio, T. Electrical conductivity of individual carbon nanotubes. Nature 1996, 382, 54-56. [CrossRef]

11. Mallakpour, S.; Soltanian, S. Surface functionalization of carbon nanotubes: Fabrication and applications. RSC Adv. 2016, 6, 109916-109935. [CrossRef]

12. Moniruzzaman, M.; Winey, K.I. Polymer Nanocomposites Containing Carbon Nanotubes. Macromolecules 2006, 39, 5194-5205. [CrossRef]

13. Fujigaya, T.; Nakashima, N. Non-covalent polymer wrapping of carbon nanotubes and the role of wrapped polymers as functional dispersants. Sci. Technol. Adv. Mater. 2015, 16, 024802. [CrossRef]

14. Jin, M.; Feng, X.; Xi, J.; Zhai, J.; Cho, K.; Feng, L.; Jiang, L. Super-Hydrophobic PDMS Surface with Ultra-Low Adhesive Force. Macromol. Rapid Commun. 2005, 26, 1805-1809. [CrossRef]

15. Wang, Y.; Huang, Z.; Gurney, R.S.; Liu, D. Superhydrophobic and photocatalytic $\mathrm{PDMS}_{\mathrm{TiO}}$ coatings with environmental stability and multifunctionality. Colloids Surf. Physicochem. Eng. Asp. 2019, 561, 101-108. [CrossRef]

16. Shena, C.; Wang, H.; Zhang, T.; Zeng, Y.J. Silica coating onto graphene for improving thermal conductivity and electrical insulation of graphene/polydimethylsiloxane nanocomposites. Mater. Res. Technol. 2019, 35, 36-43. [CrossRef]

17. Deng, W.; Lei, Y.; Lin, Y.; Zhou, S.; Zhang, A. Absorptive supramolecular elastomer wound dressing based on polydimethylsiloxane(polyethylene glycol)-polydimethylsiloxane copolymer: Preparation and characterization. RSC Adv. 2016, 6, 51694-51702. [CrossRef]

18. Kong, K.; Mariatti, M.; Rashid, A.; Busfield, J. Enhanced conductivity behavior of polydimethylsiloxane (PDMS) hybrid composites containing exfoliated graphite nanoplatelets and carbon nanotubes. Compos. Part B Eng. 2014, 58, 457-462. [CrossRef]

19. Guo, Y.; Pan, L.; Yang, X.; Ruan, K.; Han, Y.; Kong, J.; Gu, J. Simultaneous improvement of thermal conductivities and electromagnetic interference shielding performances in polystyrene composites via constructing interconnection oriented networks based on electrospinning technology. Compos. Part A Appl. Sci. Manuf. 2019, 124, 840-848. [CrossRef]

20. Meng, L.-Y.; Park, S.-J. Superhydrophobic carbon-based materials: A review of synthesis, structure, and applications. Carbon Lett. 2014, 15, 89-104. [CrossRef]

21. Klonos, P.; Sulym, I.; Borysenko, M.; Kripotou, S.; Kyritsis, A.; Pissis, P.; Gun'Ko, V. Interfacial interactions and complex segmental dynamics in systems based on silica-polydimethylsiloxane core-shell nanoparticles: Dielectric and thermal study. Polymers 2015, 58, 9-21. [CrossRef]

22. Klonos, P.; Sulym, I.; Kyriakos, K.; Vangelidis, I.; Zidropoulos, S.; Sternik, D.; Borysenko, M.; Kyritsis, A.; Deryło-Marczewska, A.; Gun'Ko, V. Interfacial phenomena in core-shell nanocomposites of PDMS adsorbed onto low specific surface area fumed silica nanooxides: Effects of surface modification. Polymers 2015, 68, 158-167. [CrossRef]

23. Klonos, P.; Dapei, G.; Sulym, I.Y.; Zidropoulos, S.; Sternik, D.; Deryło-Marczewska, A.; Borysenko, M.V.; Gun'Ko, V.M.; Kyritsis, A.; Pissis, P. Morphology and molecular dynamics investigation of PDMS adsorbed on titania nanoparticles: Effects of polymer molecular weight. Eur. Polym. J. 2016, 74, 64-80. [CrossRef]

24. Klonos, P.; Sulym, I.Y.; Sternik, D.; Konstantinou, P.; Goncharuk, O.V.; Deryło-Marczewska, A.; Gun'Ko, V.M.; Kyritsis, A.; Pissis, P. Morphology, crystallization and rigid amorphous fraction in PDMS adsorbed onto carbon nanotubes and graphite. Polymers 2018, 139, 130-144. [CrossRef]

25. Sulym, I.; Kubiak, A.; Jankowska, K.; Sternik, D.; Terpilowski, K.; Sementsov, Y.; Borysenko, M.; Derylo-Marczewska, A.; Jesionowski, T. Superhydrophobic MWCNTs/PDMS-nanocomposite materials: Preparation and characterization. Physicochem. Probl. Miner. Process. 2019, 55, 1394-1400. [CrossRef]

26. Rodgers, L.; Knott, R.; Holden, P.; Pike, K.; Hanna, J.; Foster, L.; Bartlett, J. Structural evolution and stability of sol-gel biocatalysts. Phys. B Condens. Matter. 2006, 385-386, 508-510. [CrossRef]

27. Kovalenko, G.A.; Perminova, L.V.; Beklemishev, A.B.; Parmon, V.N. Heterogeneous Biocatalysts Prepared by Immuring Enzymatic Active Components inside Silica Xerogel and Nanocarbons-In-Silica Composites. Catalysts 2018, 8, 177. [CrossRef]

28. Sarmah, N.; Revathi, D.; Sheelu, G.; Rani, K.Y.; Sridhar, S.; Mehtab, V.; Sumana, C. Recent advances on sources and industrial applications of lipases. Biotechnol. Prog. 2018, 34, 5-28. [CrossRef]

29. Rodríguez, K.; Martinez, R.; Bernal, C. Selective immobilization of Bacillus subtilis lipase A from cell culture supernatant: Improving catalytic performance and thermal resistance. Process. Biochem. 2020, 92, 214-223. [CrossRef]

30. Zdarta, J.; Norman, M.; Smułek, W.; Moszyński, D.; Kaczorek, E.; Stelling, A.L.; Ehrlich, H.; Jesionowski, T. Spongin-Based Scaffolds from Hippospongia communis Demosponge as an Effective Support for Lipase Immobilization. Catalysts 2017, 7, 147. [CrossRef] 
31. Zhang, J.; Zhang, F.; Yang, H.; Huang, X.; Liu, H.; Zhang, J.; Guo, S. Graphene Oxide as a Matrix for Enzyme Immobilization. Langmuir 2010, 26, 6083-6085. [CrossRef]

32. Asmat, S.; Anwer, A.H.; Husain, Q. Immobilization of lipase onto novel constructed polydopamine grafted multiwalled carbon nanotube impregnated with magnetic cobalt and its application in synthesis of fruit flavours. Int. J. Biol. Macromol. 2019, 140, 484-495. [CrossRef]

33. Yan, Y.; Miao, J.; Yang, Z.; Xiao, F.-X.; Yang, H.B.; Liu, B.; Yang, Y. Carbon nanotube catalysts: Recent advances in synthesis, characterization and applications. Chem. Soc. Rev. 2015, 44, 3295-3346. [CrossRef]

34. Wang, L.; Liu, X.; Jiang, Y.; Zhou, L.; Ma, L.; He, Y.; Gao, J. Biocatalytic Pickering Emulsions Stabilized by Lipase-Immobilized Carbon Nanotubes for Biodiesel Production. Catalysts 2018, 8, 587. [CrossRef]

35. Zhang, C.; Luo, S.; Chen, W. Activity of catalase adsorbed to carbon nanotubes: Effects of carbon nanotube surface properties. Talanta 2013, 113, 142-147. [CrossRef]

36. Pavlidis, I.V.; Tsoufis, T.; Enotiadis, A.; Gournis, D.; Stamatis, H. Functionalized Multi-Wall Carbon Nanotubes for Lipase Immobilization. Adv. Eng. Mater. 2010, 12, B179-B183. [CrossRef]

37. Wang, L.; Xu, R.; Chen, Y.; Jiang, R. Activity and stability comparison of immobilized NADH oxidase on multi-walled carbon nanotubes, carbon nanospheres, and single-walled carbon nanotubes. J. Mol. Catal. B Enzym. 2011, 69, 120-126. [CrossRef]

38. Feng, W.; Ji, P. Enzymes immobilized on carbon nanotubes. Biotechnol. Adv. 2011, 29, 889-895. [CrossRef] [PubMed]

39. Reis, P.; Holmberg, K.; Watzke, H.; Leser, M.; Miller, R. Lipases at interfaces: A review. Adv. Colloid Interface Sci. 2009, 147-148, 237-250. [CrossRef]

40. Kartel, M.; Sementsov, Y.; Mahno, S.; Trachevskiy, V.; Bo, W. Polymer Composites Filled with Multiwall Carbon Nanotubes. Univ. J. Mater. Sci. 2016, 4, 23-31. [CrossRef]

41. Melezhyk, A.V.; Sementsov, Y.I.; Yanchenko, V.V. Synthesis of thin carbon nanotubes on co-precipitated metaloxide catalysts. Russ. J. Appl. Chem. 2005, 78, 938-946.

42. Gun'ko, V.M. Composite materials: Textural characteristics. Appl. Surf. Sci. 2014, 307, 444-454. [CrossRef]

43. Gun'ko, V.M.; Mikhalovsky, S.V. Evaluation of slitlike porosity of carbon adsorbents. Carbon 2004, 42, 843-849. [CrossRef]

44. Gregg, S.J.; Sing, K.S.W. Adsorption, Surface Area and Porosity, 2nd ed.; Academic Press: London, UK, 1982.

45. Kruk, M.; Jaroniec, M. Gas Adsorption Characterization of Ordered Organic-Inorganic Nanocomposite Materials. Chem. Mater. 2001, 13, 3169-3183. [CrossRef]

46. Dresselhaus, M.; Dresselhaus, G.; Jorio, A.; Filho, A.S.; Saito, R. Raman spectroscopy on isolated single wall carbon nanotubes. Carbon 2002, 40, 2043-2061. [CrossRef]

47. Dresselhaus, M.; Dresselhaus, G.; Saito, R.; Jorio, A. Raman spectroscopy of carbon nanotubes. Phys. Rep. 2005, 409, 47-99. [CrossRef]

48. Johnson, L.M.; Gao, L.; Iv, C.W.S.; Smith, M.; Efimenko, K.; Cushing, K.; Genzer, J.; López, G.P. Elastomeric microparticles for acoustic mediated bioseparations. J. Nanobiotechnol. 2013, 11, 22. [CrossRef]

49. Sulym, I.; Goncharuk, O.; Sternik, D.; Terpilowski, K.; Derylo-Marczewska, A.; Borysenko, M.V.; Gun'Ko, V.M. Nanooxide/Polymer Composites with Silica@PDMS and Ceria-Zirconia-Silica@PDMS: Textural, Morphological, and Hydrophilic/Hydrophobic Features. Nanoscale Res. Lett. 2017, 12,1-10. [CrossRef]

50. Wang, S.; Li, T.; Wu, L.; Zhang, L.; Dong, L.; Hu, X.; Li, C.-Z. Second-order Raman spectroscopy of char during gasification. Fuel Process. Technol. 2015, 135, 105-111. [CrossRef]

51. Wong, P.T.; Wong, R.K.; Caputo, T.A.; Godwin, T.A.; Rigas, B. Infrared spectroscopy of exfoliated human cervical cells: Evidence of extensive structural changes during carcinogenesis. Proc. Natl. Acad. Sci. USA 1991, 88, 10988-10992. [CrossRef]

52. Portaccio, M.B.E.; Della Ventura, B.; Mita, D.G.; Manolova, N.; Stoilova, O.; Rashkov, I.; Lepore, M. FT-IR microscopy characterization of sol-gel layers prior and after glucose oxidase immobilization for biosensing applications. J. SolGel Sci. Technol. 2011, 57, 204-211. [CrossRef]

53. Colla, L.M.; Ficanha, A.M.M.; Rizzardi, J.; Bertolin, T.E.; Reinehr, C.O.; Costa, J.A.V. Production and Characterization of Lipases by Two New Isolates of Aspergillus through Solid-State and Submerged Fermentation. BioMed Res. Int. 2015, 2015, 725959. [CrossRef]

54. Zhu, Y.-T.; Ren, X.-Y.; Liu, Y.-M.; Wei, Y.; Qing, L.-S.; Liao, X. Covalent Immobilization of Porcine Pancreatic Lipase on CarboxylActivated Magnetic Nanoparticles: Characterization and Application For Enzymatic Inhibition Assays. Mater. Sci. Eng. C 2014, 38, 278-285. [CrossRef]

55. Narwal, S.K.; Saun, N.K.; Gupta, R. Characterization and Catalytic Properties of Free and Silica-Bound Lipase: A Comparative Study. J. Oleo Sci. 2014, 63, 599-605. [CrossRef]

56. Peña, S.A.; Rios, N.S.; Carballares, D.; Gonçalves, L.R.; Fernandez-Lafuente, R. Immobilization of lipases via interfacial activation on hydrophobic supports: Production of biocatalysts libraries by altering the immobilization conditions. Catal. Today 2021, 362, 130-140. [CrossRef]

57. Rodrigues, R.C.; Virgen-Ortíz, J.J.; dos Santos, J.C.; Berenguer-Murcia, Á.; Alcantara, A.R.; Barbosa, O.; Ortiz, C.; FernandezLafuente, R. Immobilization of lipases on hydrophobic supports: Immobilization mechanism, advantages, problems, and solutions. Biotechnol. Adv. 2019, 37, 746-770. [CrossRef] [PubMed]

58. Li, W.; Shen, H.; Tao, Y.; Chen, B.; Tan, T. Amino silicones finished fabrics for lipase immobilization: Fabrics finishing and catalytic performance of immobilized lipase. Process. Biochem. 2014, 49, 1488-1496. [CrossRef] 
59. Hu, Y.; Dai, L.; Liu, D.; Du, W. Hydrophobic pore space constituted in macroporous ZIF-8 for lipase immobilization greatly improving lipase catalytic performance in biodiesel preparation. Biotechnol. Biofuels 2020, 13, 1-9. [CrossRef]

60. Dong, L.; Ge, C.; Qin, P.; Chen, Y.; Xu, Q. Immobilization and catalytic properties of candida lipolytic lipase on surface of organic intercalated and modified MgAl-LDHs. Solid State Sci. 2014, 31, 8-15. [CrossRef]

61. Lee, J.H.; Kim, S.B.; Park, C.; Kim, S.W. Effect of a buffer mixture system on the activity of lipases during immobilization process. Bioresour. Technol. 2010, 101, S66-S70. [CrossRef]

62. Jamie, A.; Alshami, A.S.; Maliabari, Z.O.; Ateih, M.A.; Al Hamouz, O.C.S. Immobilization and enhanced catalytic activity of lipase on modified MWCNT for oily wastewater treatment. Environ. Prog. Sustain. Energy 2016, 35, 1441-1449. [CrossRef]

63. Khan, A.K.; Mubarak, N.M.; Abdullah, E.; Khalid, M.; Nizamuddin, S.; Baloch, H.A.; Siddiqui, M. Immobilization of Lipase Enzyme Carbon Nanotubes via Adsorption. IOP Conf. Ser. Mater. Sci. Eng. 2019, 495, 012055. [CrossRef]

64. Macario, A.; Giordano, G.; Frontera, P.; Crea, F.; Setti, L. Hydrolysis of Alkyl Ester on Lipase/Silicalite-1 Catalyst. Catal. Lett. 2007, 122, 43-52. [CrossRef]

65. Gonqalves, A.P.V.; Lopes, J.M.; Lemos, F.; Ram, F.; Ramoa Ribeiro, F.; Prazeres, D.M.F.; Cabral, J.M.S.; Aires-Barros, M. Effect of the immobilization support on the hydrolytic activity of a cutinase from Fusarium solanipisi. J. Mol. Catal. B Enzym. 1996, 1, 53-60.

66. Soumanou, M.M.; Bornscheuer, U.T. Improvement in lipase-catalyzed synthesis of fatty acid methyl esters from sunflower oil. Enzym. Microb. Technol. 2003, 33, 97-103. [CrossRef]

67. Reetz, M.T.; Zonta, A.; Simpelkamp, J. Efficient immobilization of lipases by entrapment in hydrophobic sol-gel materials. Biotechnol. Bioeng. 1996, 49, 527-534. [CrossRef]

68. Zdarta, J.; Wysokowski, M.; Norman, M.; Kołodziejczak-Radzimska, A.; Moszyński, D.; Maciejewski, H.; Ehrlich, H.; Jesionowski, T. Candida antarctica Lipase B Immobilized onto Chitin Conjugated with POSS ${ }^{\circledR}$ Compounds: Useful Tool for Rapeseed Oil Conversion. Int. J. Mol. Sci. 2016, 17, 1581. [CrossRef] [PubMed] 